Article

\title{
Developing a Landscape Sustainability Assessment Model Using an Analytic Hierarchy Process in Korea
}

\author{
Hyung-Sook Lee ${ }^{1}\left(\mathbb{C}\right.$ and Eun-Yeong Park ${ }^{2, *}$ \\ 1 Department of Landscape Architecture, Kyungpook National University, Daegu 41561, Korea; \\ soolee@knu.ac.kr \\ 2 Department of Environmental Landscape Architecture, Joongbu University, Geumsan 32713, Korea \\ * Correspondence: eypark@joongbu.ac.kr; Tel.: +82-41-750-6294
}

Received: 27 October 2019; Accepted: 27 December 2019; Published: 30 December 2019

\begin{abstract}
With the increasing interest in integrative sustainable development, there has been a strong need for a landscape sustainability assessment tool independent from the existing green building rating system. This study aimed to establish an assessment model to objectively evaluate landscape sustainability using an analytic hierarchy process (AHP). Through an extensive literature review and expert survey, an initial list of assessment items was derived and used to set up an AHP model. An AHP survey with landscape architects and architects/engineers was then conducted to determine the importance of the assessment factors. In addition, the model was applied to three projects that were previously certified by a green building rating system in Korea. The AHP results showed that "site context" ranked as the most important factor of landscape sustainability followed by "soil and vegetation," "maintenance," "water," "health and wellbeing," and "materials." Among the 20 assessment factors, "monitoring plan" was evaluated as the most important index, followed by "protection of cultural heritage" and "long-term management plan." Landscape architects evaluated "soil and vegetation" as the most important in the assessment, while the engineers/architects group rated "site context" as the most important. When tested by applying them to the previously certified projects, the developed factors provided more objective and detailed information on landscape sustainability.
\end{abstract}

Keywords: landscape sustainability; assessment model; landscape performance; analytic hierarchy process; sustainability rating system

\section{Introduction}

Active discussions are being held worldwide on ways of improving the environment, such as optimizing buildings' energy use and reducing CO2 emissions to tackle climate change [1-3]. With the increasing awareness of severe environmental problems, such as contamination of the natural environment, destruction of the ecosystem, resource depletion, water shortages, and extreme weather events, there has been a strong need for sustainable development and an environmental paradigm throughout society $[4,5]$. As an outcome of these discussions, assessment criteria on the environmental performance of buildings have been established and implemented. Led by the Building Research Establishment Environment Assessment Method (BREEAM) of the UK in 1991 [6], there has been the development of Canada's SBTool [7], Japan's Comprehensive Assessment System for Built Environment Efficiency (CASBEE) [8], Australia's Green Star [9], Singapore's Green Mark [10], and the US's Leadership in Energy and environmental Design (LEED) V1.0 enacted by the U.S. Green Building Council (USGBC) in 1998 [11-13]. Korea implemented the "Green Building Certification System" in $2002[14]$. 
The initial sustainability assessment systems focused on individual buildings, but with the increasing awareness of the importance of environmental issues occurring at the city/neighborhood levels, sustainability assessment systems worldwide have established separate landscape assessment systems at the city/neighborhood levels in addition to those for individual buildings. The US, in particular, has been implementing the Sustainable Sites Initiative (SITES) since 2012, apart from its existing green building certification system LEED, through which various landscape sustainability factors of all project sites are assessed regardless of buildings. This has also led to sustainable and integrated design, from development planning of the project site to design and management [11]. However, while the ecology category of the Green Standard for Energy and Environmental Design (G-SEED), Korea's green building rating system, includes sustainability assessment items related to landscape and external environment, this is strictly limited. G-SEED can only assess projects that include buildings and, thus, it is inadequate for assessing various forms of landscapes or parks, green spaces, and other facilities [15].

Precedent studies on landscape assessment systems have comparatively analyzed the BREEAM, LEED, and CASBEE [15-18], and some have examined the similarities and differences by comparing the BREEAM and LEED with Korea's green building rating system [19,20]. Studies on green space have either comparatively analyzed the sustainability of apartment complexes [21], Seoul's new built-up areas and green spaces in new town housing complexes of metropolitan areas [22], using the assessment items of "land use and transportation" and "ecological environment" in Korea's Green Building Certification System, or established village-type sustainability factors [23]. These studies have performed landscape assessment using the limited green space assessment items of the certification system that targets buildings. The studies related to sustainability assessment factors have used various methods, such as literature reviews [4,13], the Delphi method [24,25], expert surveys [26,27], and field surveys [3,28,29].

Recently in Korea, there has been a need for an independent system of landscape sustainability assessment, and active discussions have been made accordingly. However, there is a gap in the perception of sustainability assessments for outdoor spaces and landscapes as well as directions for improvement between non-landscape experts, such as architects/engineers, and landscape experts $[11,30]$. The purpose of the research is to analyze the possibility of using an analytic hierarchy process (AHP) as a decision-making tool in the process of selecting the assessment items for a landscape sustainability rating system. This study established the following three objectives:

(1) to establish an assessment model to objectively evaluate landscape sustainability;

(2) to comparatively analyze the importance of assessment factors by landscape architects and non-landscape architects;

(3) to test the applicability of the model developed in this study by applying it to G-SEED-certified projects.

\section{Methodology}

\subsection{Research Scope and Sampling}

The assessment items in this study were limited to assessment criteria that may be used to establish or remodel outdoor spaces of buildings, parks, and green areas in urban or suburban areas. Assessment criteria for sustainable buildings or community environment were excluded. In the current situation, where only building certification exists in Korea, we focused on developing assessment criteria that may be used as basic data to establish sustainability certification for landscaping and outdoor spaces in the future.

Interviews and surveys were employed to collect data in this study. The sample for the AHP survey included 70 landscape architecture experts as well as 71 engineers/architects who had experience in the G-SEED certification process. Given the discrepancy between the landscape architect group 
and the architects/engineers group in terms of perception on landscape sustainability rating systems, purposive sampling techniques were employed to select the respondents from the two groups.

\subsection{Analytic Hierarchy Process (AHP)}

The analytic hierarchy process (AHP) is one of the most widely used methods in multi-attribute decision making. The AHP, developed by Thomas Saaty in 1977, was designed to help decision makers incorporate qualitative and quantitative aspects of a complex problem with multiple subjective criteria. It is considered a promising framework for evaluation due to its potential to explicitly take into account conflictual, incommensurable, and uncertain effects of decisions. The AHP involves the following basic steps: (1) the building of a hierarchical AHP model consisting of criteria and factors of the problem, (2) pairwise comparisons between elements at each level to derive the weights and relative priorities of factors, and (3) the synthesis of the priorities of the criteria for weights into an overall rating based on which best alternative is decided.

The strength of the AHP method lies in its ability to reduce complex decisions to a series of one-on-one comparisons by assisting with identifying and weighting selection criteria, analyzing the data collected for the criteria, and expediting the decision-making process [31]. Comparisons can be made according to preference, importance, or likelihood, whichever is most appropriate for the elements considered.

The AHP has already been applied for developing sustainability assessment systems, such as sustainable community rating tools [23], Korean traditional house sustainability [32], and sustainable interior material [33]. The AHP is implemented using Expert Choice software, which can provide visualized results.

\subsection{Research Framework}

In this study, we prioritized the factors for assessing landscape sustainability and developed an assessment model using the AHP method. The process of our study went through three stages for assessing landscape sustainability, involving (1) defining the assessment criteria and factors, (2) identifying the weights of criteria and factors through the AHP method, and (3) applying the assessment model to G-SEED-certified projects.

The overall research process is presented in Figure 1, and the following subchapters describe each phase in detail.

\begin{tabular}{|c|c|c|}
\hline Phase & Purpose & Methodology \\
\hline Phase 1 & $\begin{array}{c}\text { Defining } \\
\text { assessment criteria } \\
\text { and factors }\end{array}$ & $\begin{array}{l}\text { - Deriving assessment factors through review of previous } \\
\text { assessment tools. } \\
\text { - Conducting unstructured interviews with experts for } \\
\text { elaborating initial set of criteria and factors. } \\
\text { - Performing the preliminary survey to reflect opinions of } \\
\text { landscape professionals. }\end{array}$ \\
\hline \multicolumn{3}{|c|}{$\downarrow$} \\
\hline Phase 2 & $\begin{array}{l}\text { Identifying } \\
\text { weights of criteria } \\
\text { and factors } \\
\text { through AHP } \\
\text { method }\end{array}$ & $\begin{array}{l}\text { - Developing the AHP model. } \\
\text { - Conducting the AHP survey among landscape } \\
\text { practitioners and architects to determine weight of } \\
\text { priorities. } \\
\text { - Determining importance of evaluation items. }\end{array}$ \\
\hline \multicolumn{3}{|c|}{$\downarrow$} \\
\hline Phase 3 & $\begin{array}{l}\text { Applying the } \\
\text { model }\end{array}$ & $\begin{array}{l}\text { - Testing applicability of landscape sustainability factors by } \\
\text { assessing three G-SEED-certified projects. }\end{array}$ \\
\hline
\end{tabular}

Figure 1. Research flowchart. 


\subsubsection{Phase I: Defining the Criteria and Factors}

An extensive review of precedent research and previous evaluation instruments related to landscape sustainability was performed in order to determine the initial set of assessment factors. A variety of factors concerning outdoor or landscape sustainability were derived from the existing rating systems, including LEED, Leadership in Energy and Environmental Design for New Construction (LEED-NC), Leadership in Energy and Environmental Design for Neighborhood Development (LEED-ND), SITES, Seattle Green Factor, and Helsinki Green Factor [14,34-39] (Table 1).

We conducted unstructured interviews with five experts in landscape architecture in order to elaborate the initial criteria and factors from the literature review. The experts checked if the initial sets of factors were mutually exclusive and non-redundant. Based on their comments, a total of 6 criteria and 34 factors were generated.

Since assessment factors should be defined based on expert knowledge and the local context of Korea, we conducted the unstructured interviews with 11 practitioners from landscape architecture firms. The interviewees were asked to identify which factors they considered most important for the assessment of landscape sustainability to develop a new assessment system on a 5-point Likert scale. The interviewees had 10-25 years' experience as practitioners in the field of landscape planning and design. As a result of the interviews, 20 items in six criteria were selected.

\subsubsection{Phase II: Identifying the Weights of Criteria and Factors through the AHP Method}

An AHP model was formatted based on the literature review and expert interviews (Figure 2). In addition, an AHP questionnaire was designed with a pairwise comparison format to give the relative importance among the criteria and factors. The values of importance were based on a 9-point scale, with a value of 9 indicating the absolute importance of one item over the other and a value of 1 meaning equal importance. Table 2 shows the AHP pairwise comparison scale.

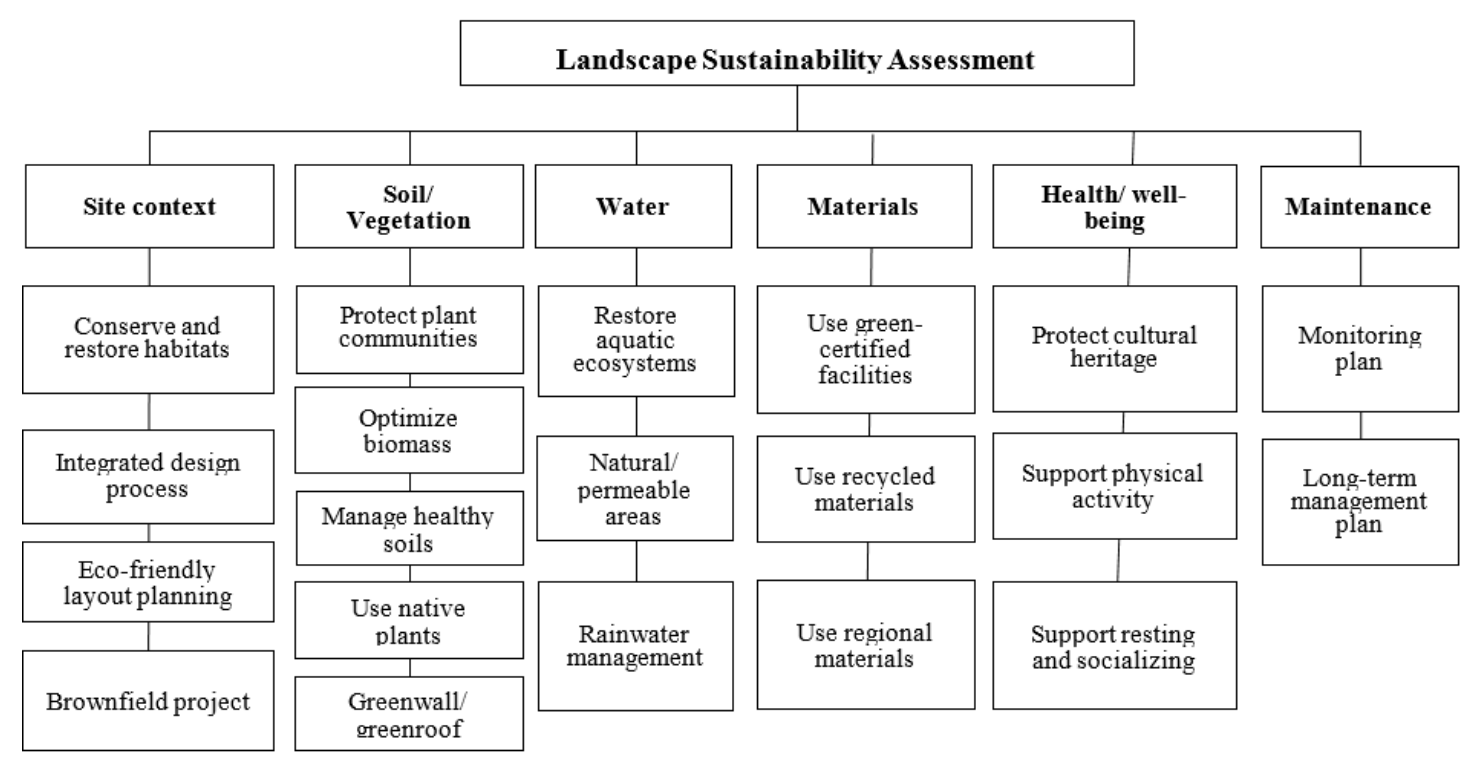

Figure 2. Analytic hierarchy process model. 
Table 1. Derivation of landscape sustainability assessment factors.

\begin{tabular}{|c|c|c|c|c|c|}
\hline \multirow{3}{*}{ Criteria } & \multicolumn{5}{|c|}{ Items of Existing Rating Systems and Assessment Subject } \\
\hline & G-SEED & LEED-NC/ND & SITES & Seattle Green Factor & Helsinki Green Factor \\
\hline & Building & Neighborhood Development & Landscape & Greenery & Greenery \\
\hline Site context & $\begin{array}{ll}- & \begin{array}{l}\text { Ecological value of } \\
\text { existing site }\end{array} \\
\text { - } & \text { Outside pedestrian } \\
\text { walkway network } \\
\text { - } & \begin{array}{l}\text { Proximity of } \\
\text { public transportation }\end{array}\end{array}$ & $\begin{array}{l}\text { - } \quad \text { Brownfield redevelopment } \\
\text { - Smart location }\end{array}$ & $\begin{array}{ll}\text { - } & \text { Select brownfields or grayfields } \\
\text { for redevelopment } \\
\text { - } & \text { Preserve threatened or endangered } \\
\text { species and their habitats } \\
\text { - Use integrated site } \\
\text { development process }\end{array}$ & $\begin{array}{ll}- & \text { Landscaped areas } \\
\text { - } & \text { Bio-retention facilities }\end{array}$ & \\
\hline Soil/vegetation & $\begin{array}{ll}\text { - } & \text { Biotope creation } \\
\text { - } & \text { Green network } \\
\text { - } & \text { Ecological area ratio }\end{array}$ & $\begin{array}{l}\text { - } \quad \text { Protect or restore habitat } \\
\text { pistoric resource } \\
\text { preservation and } \\
\text { adaptive use }\end{array}$ & $\begin{array}{ll}- & \text { Minimize soil disturbance in design } \\
\text { and construction } \\
\text { - } \\
\text { - }\end{array}$ & $\begin{array}{ll}\text { - } & \text { Plantings } \\
\text { - } & \text { Green roofs } \\
\text { - } & \text { Structurated walls } \\
\text { - } & \text { Drought tolerance of } \\
& \text { native plant species }\end{array}$ & $\begin{array}{ll}- & \text { Preserved vegetation } \\
& \text { and soil } \\
\text { - } & \text { Planted/new vegetation } \\
\text { - } & \text { Green roofs } \\
\text { - } & \text { Green walls, vertical areas }\end{array}$ \\
\hline Water & $\begin{array}{ll}\text { - } & \text { Validity of rainwater load } \\
& \text { reduction measures } \\
\text { - } & \text { Rainwater utilization } \\
\text { - } & \text { Install graywater }\end{array}$ & $\begin{array}{l}\text { - } \quad \text { Protect or restore habitat } \\
\text { Site design for habitat or } \\
\text { wetland and water } \\
\text { body conservation }\end{array}$ & $\begin{array}{l}\text { - Preserve wetlands } \\
\text { - Protect and restore riparian areas, } \\
\text { wetlands, and shoreline buffers } \\
\text { - Rehabilitate lost streams, wetlands, } \\
\text { and shorelines } \\
\text { - Manage stormwater on site }\end{array}$ & $\begin{array}{ll}\text { - } & \text { Approved } \\
\text { water features } \\
\text { - } \quad \text { Use of } \\
\text { harvested rainwater } \\
\text { - } & \text { Permeable paving }\end{array}$ & $\begin{array}{ll}\text { - } & \text { Permeable pavement } \\
\text { - } & \text { Rain garden } \\
\text { - } & \text { Stormwater } \\
\text { - } & \text { Wetland } \\
\text { - } & \text { Infiltration pit } \\
\text { - } & \text { Retention swale covered } \\
& \text { with natural vegetation } \\
\text { - } & \text { Selection of native species }\end{array}$ \\
\hline Materials & $\begin{array}{ll}\text { - } & \text { Use of certified green } \\
\text { products for effective } \\
\text { recycling (prerequisite) } \\
\text { Information display for } \\
\text { carbon emissions of materials }\end{array}$ & & $\begin{array}{l}\text { - Use recycled content materials } \\
\text { - Use regional materials }\end{array}$ & & $\begin{array}{l}\text { - Tree species native to } \\
\text { Helsinki and flowering trees } \\
\text { and shrubs }\end{array}$ \\
\hline Health/wellbeing & $\begin{array}{l}\text { - } \quad \text { Community facility } \\
\text { - Whether to create pedestrian } \\
\text { walkway inside complex } \\
\text { - Whether to install bike storage } \\
\text { and bike road }\end{array}$ & $\begin{array}{ll}\text { - } & \text { Maximize open space } \\
\text { - } & \text { Historic resource } \\
\text { preservation and } \\
\text { adaptive use }\end{array}$ & $\begin{array}{ll}\text { - } & \text { Protect and maintain unique } \\
\text { cultural and historical places } \\
\text { - } & \text { Provide opportunities for outdoor } \\
\text { physical activity } \\
\text { - }\end{array}$ & $\begin{array}{l}\text { - Adjacent public right } \\
\text { of way or public } \\
\text { open spaces }\end{array}$ & \\
\hline Maintenance & $\begin{array}{ll} & \text { Rationality of site } \\
\text { management plans } \\
\text { considering the environment }\end{array}$ & & $\begin{array}{l}\text { - Monitor performance of sustainable } \\
\text { design practices }\end{array}$ & & \\
\hline
\end{tabular}


Table 2. AHP pairwise comparison scale (source: Saaty 1977).

\begin{tabular}{cc}
\hline Intensity of Relative Importance & Definition \\
\hline 1 & Equal importance \\
3 & Weak importance \\
5 & Essential or strong importance \\
7 & Demonstrated importance \\
9 & Absolute importance \\
$2,4,6$, and 8 & Intermediate values between two adjacent judgments \\
\hline
\end{tabular}

A total of 183 copies of the questionnaire were distributed to experts from different fields, such as landscape architecture, architecture, and engineering, via e-mail in October of 2018. The respondents ranged in age between $20 \mathrm{~s}$ and $60 \mathrm{~s}$ and had 3-43 years' experience in practice. While the response rate was $100 \%$, only 141 responses whose consistency ratio (CR) was less than 0.19 were used for further analysis. The CR value reflects the internal consistency and values of $C R \leq 0.2$ were also accepted [40]. The respondents were composed of landscape architects (49.6\%) and engineers/architects (50.4\%) (Table 3).

Table 3. Demographic data of respondents.

\begin{tabular}{ccccc}
\hline & & $\begin{array}{c}\text { Landscape } \\
\text { Architects }(\boldsymbol{n}=\mathbf{7 0})\end{array}$ & $\begin{array}{c}\text { Engineers/Architects } \\
(\boldsymbol{n}=\mathbf{7 1})\end{array}$ & Total $(\boldsymbol{n}=\mathbf{1 4 1})$ \\
\hline \multirow{2}{*}{ Gender } & Male & $47(33.3 \%)$ & $63(44.7 \%)$ & $110(78 \%)$ \\
& Female & $23(16.3 \%)$ & $8(5.7 \%)$ & $31(22 \%)$ \\
\hline \multirow{2}{*}{ Age } & $20 \mathrm{~s}$ & $20(14.2 \%)$ & $8(5.7 \%)$ & $28(19.8 \%)$ \\
& $30 \mathrm{~s}$ & $36(25.5 \%)$ & $26(18.4 \%)$ & $62(44.0 \%)$ \\
\hline \multicolumn{2}{c}{ Practitioner experience (average years) } & $14(10 \%)$ & $37(26.2 \%)$ & $51(36.2 \%)$ \\
\hline
\end{tabular}

Expert Choice, decision-making software developed to implement the AHP, was used to produce weights, consistency ratios, and rankings. All the comparisons were synthesized to rank the assessment items. The output of the AHP was a prioritized ranking of the assessment items based on the overall importance expressed by the participants.

\subsubsection{Phase III: Applying the Developed Assessment System}

We tested the applicability of the developed assessment system by assessing three projects that were previously certified by G-SEED, a sustainable building rating system in Korea. The three G-SEED-certified projects-an office campus landscape, hotel and commercial building landscape, and housing complex landscape-had different characteristics in terms of site area, landscape area, design intentions, etc. (Table 4). For the assessment, each item was rated on a 5-point Likert scale for sustainability by nine experts who had participated in the projects, and the means as well as previously derived weightings were considered in calculating the percentages of each field and project. 
Table 4. Study sites used to test developed assessment factors.

\begin{tabular}{|c|c|c|c|}
\hline & LH-HQ & Renaissance & Sejong \\
\hline Project type & Company building & Hotel and business district & Housing complex \\
\hline Total area & $97,165.70 \mathrm{~m}^{2}$ & $18,489.70 \mathrm{~m}^{2}$ & $7,261,643 \mathrm{~m}^{2}$ \\
\hline Location & Jinju, Gyeongsangnam-do & Gangnam-gu, Seoul & Dajeong-dong, Sejong \\
\hline Landscape area & $30,690 \mathrm{~m}^{2}(31.59 \%)$ & $2954 \mathrm{~m}^{2}(15.98 \%)$ & $33,891 \mathrm{~m}^{2}(46.67 \%)$ \\
\hline \multicolumn{4}{|l|}{ View of overall site } \\
\hline
\end{tabular}

\section{Results}

\subsection{The Relative Importance of Criteria and Factors}

Table 5 and Figure 3 show the results of the AHP survey. With respect to the results of the weightings of the six criteria, "site context" ranked as the most important factor of landscape sustainability, representing about $21.0 \%$ of the total certification, followed by "soil and vegetation," with a weighting of about $19.7 \%$. The weightings of these two criteria represented more than $40 \%$ of the total. The weightings of the "maintenance" and "water" criteria were $17.9 \%$ and $16.7 \%$, respectively. "Health and wellbeing" (14.4\%) and "materials" (10.3\%) were evaluated as having relatively low importance. 
Table 5. Weights of assessment criteria and factors.

\begin{tabular}{|c|c|c|c|c|c|c|c|}
\hline \multicolumn{3}{|c|}{ Criteria. } & \multicolumn{5}{|c|}{ Factors } \\
\hline Content & $\begin{array}{l}\text { Local } \\
\text { Rank }\end{array}$ & $\begin{array}{c}\text { Local } \\
\text { Weight }\end{array}$ & Content & $\begin{array}{l}\text { Local } \\
\text { Rank }\end{array}$ & $\begin{array}{c}\text { Local } \\
\text { Weight }\end{array}$ & $\begin{array}{l}\text { Global } \\
\text { Rank }\end{array}$ & $\begin{array}{l}\text { Global } \\
\text { Weight }\end{array}$ \\
\hline \multirow{4}{*}{$\begin{array}{l}\text { Site } \\
\text { context }\end{array}$} & \multirow{4}{*}{1} & \multirow{4}{*}{0.210} & $\begin{array}{c}\text { Conserve and restore } \\
\text { habitats }\end{array}$ & 1 & 0.32 & 5 & 0.067 \\
\hline & & & Integrated design process & 2 & 0.301 & 6 & 0.063 \\
\hline & & & $\begin{array}{l}\text { Eco-friendly layout } \\
\text { planning }\end{array}$ & 3 & 0.243 & 9 & 0.051 \\
\hline & & & Brownfield project & 4 & 0.136 & 18 & 0.029 \\
\hline \multirow{5}{*}{$\begin{array}{c}\text { Soil \& } \\
\text { vegetation }\end{array}$} & \multirow{5}{*}{2} & \multirow{5}{*}{0.197} & $\begin{array}{l}\text { Protect plant } \\
\text { communities }\end{array}$ & 1 & 0.283 & 8 & 0.056 \\
\hline & & & Optimize biomass & 2 & 0.237 & 10 & 0.047 \\
\hline & & & Reuse/recycle topsoil & 3 & 0.190 & 12 & 0.036 \\
\hline & & & Use native plants & 4 & 0.168 & 16 & 0.033 \\
\hline & & & Green wall/green roof & 5 & 0.131 & 19 & 0.026 \\
\hline \multirow{2}{*}{ Maintenance } & \multirow{2}{*}{3} & \multirow{2}{*}{0.179} & Monitoring plan & 1 & 0.582 & 1 & 0.104 \\
\hline & & & $\begin{array}{l}\text { Long-term management } \\
\text { plan }\end{array}$ & 2 & 0.418 & 3 & 0.075 \\
\hline \multirow{3}{*}{ Water } & \multirow{3}{*}{4} & \multirow{3}{*}{0.167} & $\begin{array}{c}\text { Restore aquatic } \\
\text { ecosystems }\end{array}$ & 1 & 0.431 & 4 & 0.072 \\
\hline & & & Natural/permeable areas & 2 & 0.359 & 7 & 0.06 \\
\hline & & & Rainwater management & 3 & 0.210 & 15 & 0.035 \\
\hline \multirow{3}{*}{$\begin{array}{l}\text { Health \& } \\
\text { wellbeing }\end{array}$} & \multirow{3}{*}{5} & \multirow{3}{*}{0.144} & Protect cultural heritage & 1 & 0.520 & 2 & 0.075 \\
\hline & & & Support physical activity & 2 & 0.251 & 14 & 0.036 \\
\hline & & & $\begin{array}{l}\text { Support resting and } \\
\text { socializing }\end{array}$ & 3 & 0.230 & 17 & 0.033 \\
\hline \multirow{3}{*}{ Materials } & \multirow{3}{*}{6} & \multirow{3}{*}{0.103} & $\begin{array}{l}\text { Use green-certified } \\
\text { facilities }\end{array}$ & 1 & 0.431 & 11 & 0.044 \\
\hline & & & Use recycled materials & 2 & 0.353 & 13 & 0.036 \\
\hline & & & Use regional materials & 3 & 0.217 & 20 & 0.022 \\
\hline
\end{tabular}

With regard to the "site context" category, "conserve and restore habitats" (0.320) was found to be the most important, followed by "integrated design process" (0.301), "eco-friendly layout planning" (0.243), and "brownfield project" (0.136). Within the "soil and vegetation" category, "protect plant communities" (0.283) was found to be the most important, followed by "optimize biomass" (0.237) and "manage healthy soils" (0.190). "Restore aquatic ecosystems" (0.431) was evaluated as having higher importance within the "water" category than "natural/permeable areas" (0.359) and "rainwater management" (0.210). Among the items in the "health and wellbeing" category, "protection of cultural heritage" (0.520) had a considerably higher weight than "support physical activity" (0.251) and "support resting and socializing" (0.230), emphasizing the importance of preserving the history and culture of the existing site. Within the materials category, "use green-certified facilities" (0.431) had a higher weight than "use recycled materials" (0.353). The item of "use regional materials" (0.217) had the lowest weight. 


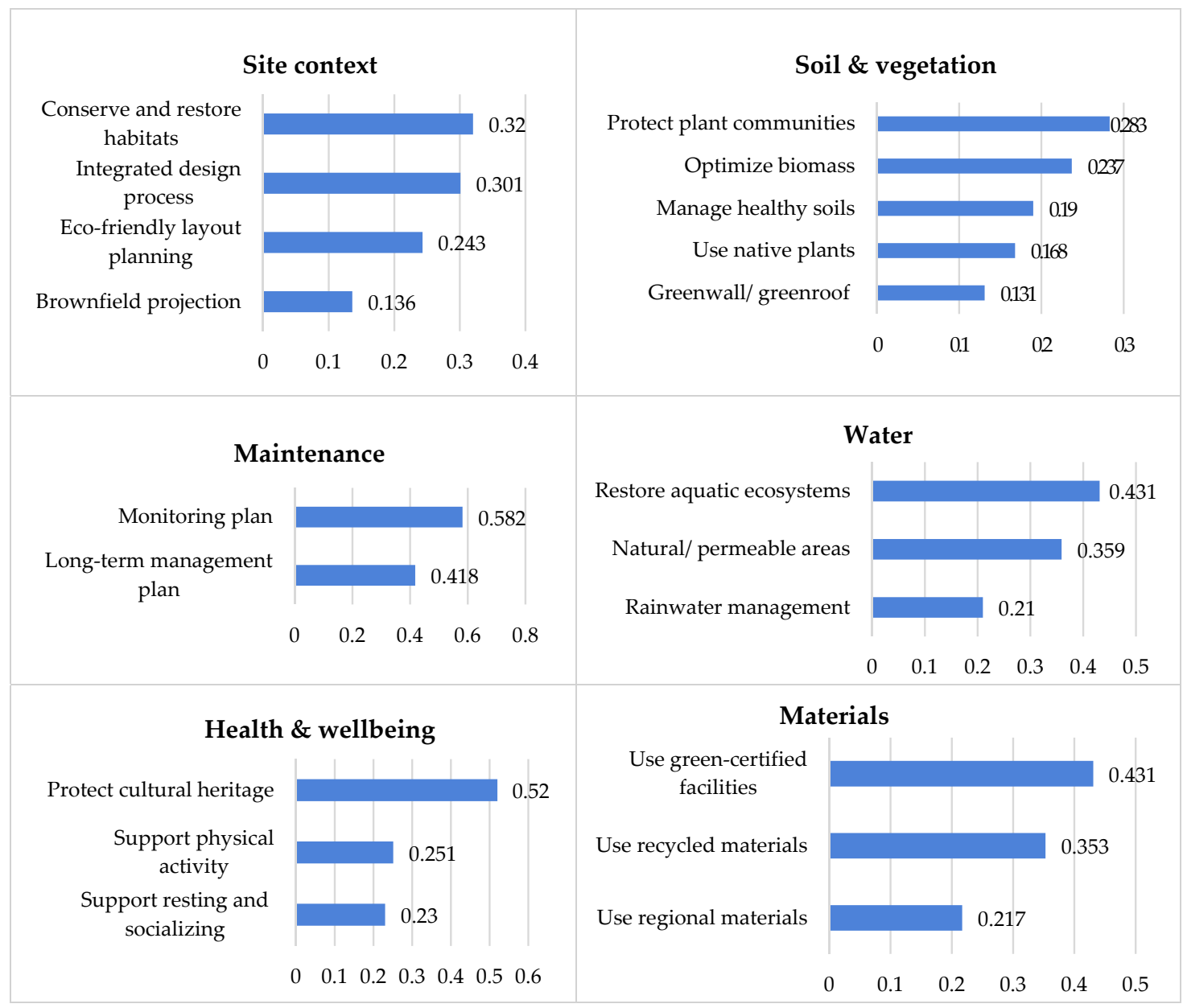

Figure 3. Relative weights of assessment factors of AHP.

\subsection{Comparison of Importance in Different Professions}

We investigated the differences of priorities between the landscape architects group and the engineers/architects group. Landscape architects evaluated "soil and vegetation" as the most important in the assessment, while the engineers/architects group evaluated "site context" as the most important. For the landscape architects group, "site context" came second in the weighting, followed by "water," "maintenance," "health and wellbeing," and "materials." On the contrary, the order of importance for the engineers group was "maintenance," "health and wellbeing," "soil and vegetation," "water," and "materials" (Table 6). Figure 4 illustrates the differences of importance between the two groups.

Table 6. Comparison of rankings between landscape architects and engineers/architects groups.

\begin{tabular}{ccccccc}
\hline \multirow{2}{*}{ Rank } & \multicolumn{2}{c}{ Total $(\boldsymbol{n}=\mathbf{1 4 1})$} & \multicolumn{2}{c}{ Landscape Architects $(\boldsymbol{n}=\mathbf{7 0})$} & \multicolumn{2}{c}{ Engineers/Architects $(\boldsymbol{n}=\mathbf{7 1})$} \\
\cline { 2 - 6 } & Category & Weighting & Category & Weighting & Category & Weighting \\
\hline 1 & Site context & 0.210 & Soil/vegetation & 0.235 & Site context & 0.211 \\
2 & Soil/vegetation & 0.197 & Site context & 0.206 & Maintenance & 0.185 \\
3 & Maintenance & 0.179 & Water & 0.171 & Health/wellbeing & 0.165 \\
4 & Water & 0.167 & Maintenance & 0.171 & Soil/vegetation & 0.164 \\
5 & Health/wellbeing & 0.144 & Health/wellbeing & 0.123 & Water & 0.162 \\
6 & Materials & 0.103 & Materials & 0.094 & Materials & 0.112 \\
\hline
\end{tabular}




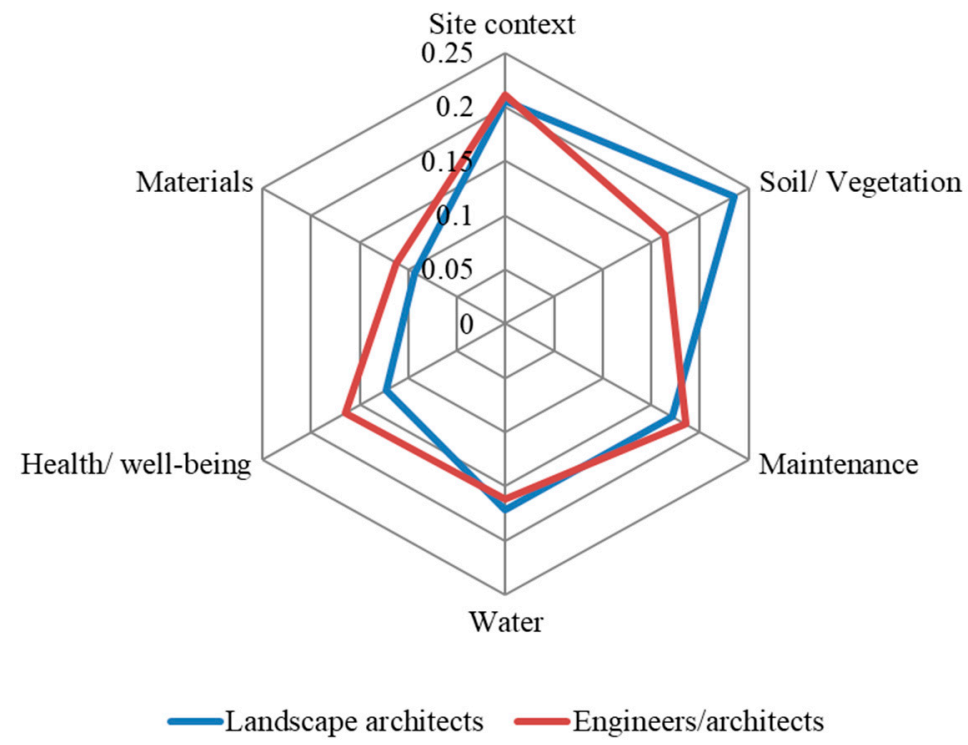

Figure 4. Discrepancy of importance in landscape sustainability criteria.

\subsection{Application of the Landscape Sustainability Model to G-SEED-Certified Projects}

Table 7 shows the results of applying the weightings derived from the AHP to the three G-SEED-certified projects. The AHP weightings were multiplied by mean scores of experts for each item, and the ratio of individual weighted scores out of total scores was calculated. Total weighted point of each project was $3.43,2.52$, and 2.56. There was also a big difference in the level of sustainability among items and criteria within a single project.

LH-HQ obtained higher scores than the other two projects mainly in "maintenance" and "health/wellbeing" criteria. By item, the scores were high in "monitoring plan" (0.46), "long-term management plan" (0.32), and "natural/permeable areas" (0.30). This is because the project had the locational benefit of securing natural soil and provided many exercise facilities/rest areas. It obtained high scores in the maintenance criteria, especially since there was a landscape maintenance plan. Renaissance Hotel showed high scores in "monitoring plan" (0.32) and "protection of cultural heritage" $(0.23)$ because it preserved architectural history in a high-density area in downtown Seoul. The Sejong construction showed relatively high scores in "support resting and socializing" (0.13) and "support physical activity" (0.14). Being a housing complex, it obtained relatively high scores in the "health and wellbeing" category, which benefits residents more directly compared to other items.

As a result of comparing the mean weighted scores in the six criteria (Figure 5), it was found that the distribution of the scores in each category shared a similar trend among the three projects. In other words, "maintenance" showed relatively higher mean scores than the other criteria. On the other hand, "water" showed lower mean scores than the other criteria at 0.12, 0.09, and 0.10, respectively. Accordingly, it was discovered that the G-SEED-certified projects in Korea are concentrated on certain criteria in terms of landscape sustainability, whereas other criteria are considered relatively less important. 
Table 7. Application of developed assessment factors to Green Standard for Energy and Environmental Design certified projects.

\begin{tabular}{|c|c|c|c|c|c|c|c|c|c|c|c|}
\hline \multirow[b]{2}{*}{ Criteria } & \multirow[b]{2}{*}{ Index } & \multirow[b]{2}{*}{ Weight } & \multicolumn{3}{|c|}{ LH-HQ } & \multicolumn{3}{|c|}{ Renaissance } & \multicolumn{3}{|c|}{ Sejong } \\
\hline & & & Point & $\begin{array}{l}\text { Weigh-Ted } \\
\text { Point }\end{array}$ & $\%$ & Point & $\begin{array}{l}\text { Weigh-Ted } \\
\text { Point }\end{array}$ & $\%$ & Point & $\begin{array}{l}\text { Weigh-Ted } \\
\text { Point }\end{array}$ & $\%$ \\
\hline \multirow{4}{*}{ Site context } & Conserve and restore habitats & 0.067 & 2.11 & 0.14 & $4.1 \%$ & 2.22 & 0.15 & $5.9 \%$ & 1.89 & 0.13 & $4.9 \%$ \\
\hline & Integrated design process & 0.063 & 4.22 & 0.27 & $7.7 \%$ & 3 & 0.19 & $7.5 \%$ & 3.22 & 0.20 & $7.9 \%$ \\
\hline & Eco-friendly layout planning & 0.051 & 4 & 0.20 & $5.9 \%$ & 2.11 & 0.11 & $4.3 \%$ & 3.11 & 0.16 & $6.2 \%$ \\
\hline & Brownfield project & 0.029 & 3.67 & 0.11 & $3.1 \%$ & 2.33 & 0.07 & $2.7 \%$ & 2.56 & 0.07 & $2.9 \%$ \\
\hline \multirow{5}{*}{ Soil/vege- tation } & Protect plant communities & 0.056 & 2.33 & 0.13 & $3.8 \%$ & 2.78 & 0.16 & $6.2 \%$ & 2.11 & 0.12 & $4.6 \%$ \\
\hline & Optimize biomass & 0.047 & 4.22 & 0.20 & $5.8 \%$ & 3 & 0.14 & $5.6 \%$ & 3.67 & 0.17 & $6.7 \%$ \\
\hline & Manage healthy soils & 0.036 & 2.44 & 0.09 & $2.6 \%$ & 1.78 & 0.06 & $2.5 \%$ & 1.89 & 0.07 & $2.7 \%$ \\
\hline & Use native plants & 0.033 & 3.67 & 0.12 & $3.5 \%$ & 2.89 & 0.10 & $3.8 \%$ & 3.22 & 0.11 & $4.1 \%$ \\
\hline & Green wall/green roof & 0.026 & 4.11 & 0.11 & $3.1 \%$ & 3.11 & 0.08 & $3.2 \%$ & 3.22 & 0.08 & $3.3 \%$ \\
\hline \multirow{2}{*}{ Mainte- nance } & Monitoring plan & 0.104 & 4.44 & 0.46 & $13.5 \%$ & 3.11 & 0.32 & $12.8 \%$ & 3 & 0.31 & $12.2 \%$ \\
\hline & Long-term management plan & 0.075 & 4.22 & 0.32 & $9.2 \%$ & 2.78 & 0.21 & $8.3 \%$ & 2.67 & 0.20 & $7.8 \%$ \\
\hline \multirow{3}{*}{ Water } & Restore aquatic ecosystems & 0.072 & N.A. & N.A. & N.A. & N.A. & N.A. & N.A. & N.A. & N.A. & N.A. \\
\hline & Natural/permeable areas & 0.06 & 5 & 0.30 & $8.7 \%$ & 3 & 0.18 & $7.1 \%$ & 3 & 0.18 & $7.0 \%$ \\
\hline & Rainwater management & 0.035 & 3.11 & 0.11 & $3.2 \%$ & 2.44 & 0.09 & $3.4 \%$ & 2.89 & 0.10 & $3.9 \%$ \\
\hline \multirow{3}{*}{ Health/wellbeing } & Protection of cultural heritage & 0.075 & 2.67 & 0.20 & $5.8 \%$ & 3.11 & 0.23 & $9.2 \%$ & 1.22 & 0.09 & $3.6 \%$ \\
\hline & Support physical activity & 0.036 & 4.78 & 0.17 & $5.0 \%$ & 2.33 & 0.08 & $3.3 \%$ & 3.89 & 0.14 & $5.5 \%$ \\
\hline & $\begin{array}{l}\text { Support resting and } \\
\text { socializing }\end{array}$ & 0.033 & 4.67 & 0.15 & $4.5 \%$ & 3 & 0.10 & $3.9 \%$ & 4 & 0.13 & $5.2 \%$ \\
\hline \multirow{4}{*}{ Materials } & Use green-certified facilities & 0.044 & 4 & 0.18 & $5.1 \%$ & 2.78 & 0.12 & $4.9 \%$ & 3.33 & 0.15 & $5.7 \%$ \\
\hline & Use recycled materials & 0.036 & 3 & 0.11 & $3.1 \%$ & 2.22 & 0.08 & $3.2 \%$ & 2.33 & 0.08 & $3.3 \%$ \\
\hline & Use regional materials & 0.022 & 3.22 & 0.07 & $2.1 \%$ & 2.56 & 0.06 & $2.2 \%$ & 2.89 & 0.06 & $2.5 \%$ \\
\hline & Total & 1 & 68.61 & 3.43 & $100.0 \%$ & 50.55 & 2.52 & $100.0 \%$ & 54.11 & 2.56 & $100.0 \%$ \\
\hline
\end{tabular}




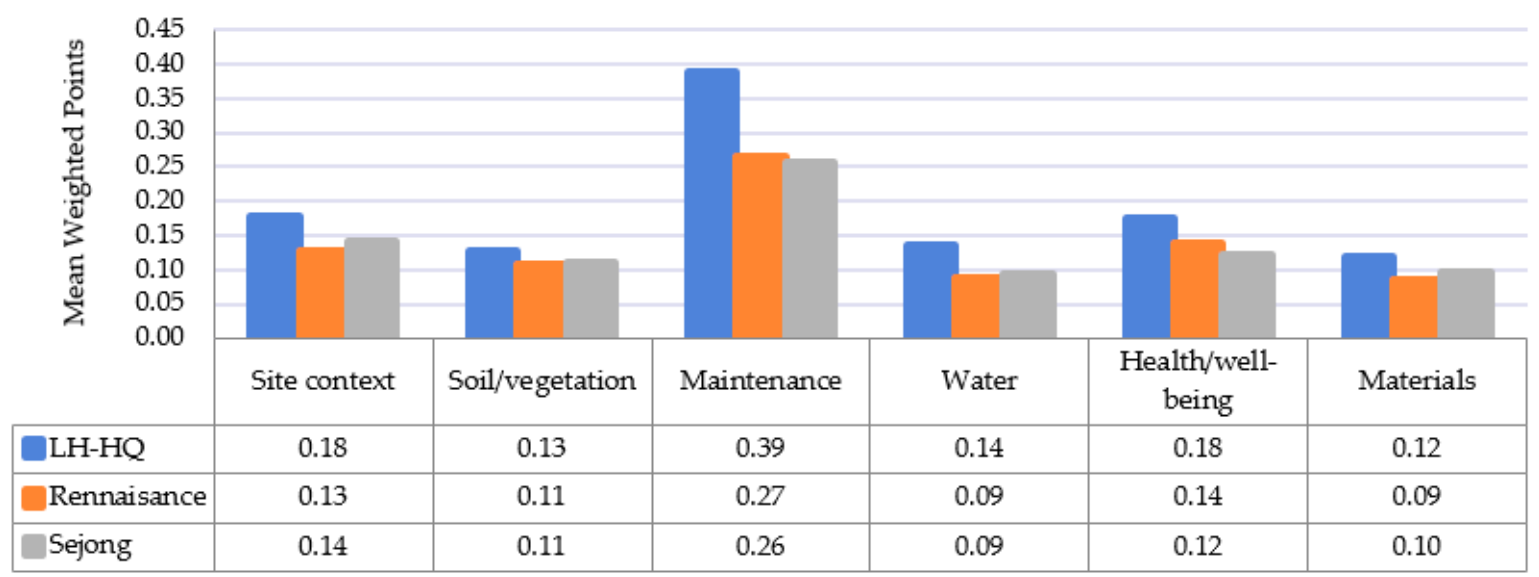

Figure 5. Results of application of assessment system.

\section{Discussion}

The following discussions can be had to develop assessment factors to objectively evaluate landscape sustainability.

First, as a result of applying the AHP to the newly derived items, "site context" and "soil and vegetation" showed the highest weightings in the main criteria, while "monitoring plan" showed the highest weighting in the sub-criteria, followed by "protection of cultural heritage" and "long-term management plan." This result is similar to that of a study on factors for planning green apartment houses [21], which showed the highest importance in "principle of efficient use of land," and that of a study on improving the Green Building Certification System for sustainable urban development [16], which showed the highest importance in "site selection and preservation."

There were also some differences between the items considered important in overseas landscape sustainability rating systems and the results of the Korean working-level assessment of importance. For example, items such as "select brownfields or grayfields for redevelopment," "preservation of soil and prevention of soil disturbance," and "use recycled materials and regional materials" had a high distribution of scores in the SITES but showed low importance in Korea. Items not covered in G-SEED, such as "protection of cultural heritage," "user health and wellbeing," "monitoring plan," and "long-term management plan," also turned out to be important, indicating that there is an emphasis on comprehensive approaches, such as integrated planning and the design process.

In terms of sustainability assessment items, there was not much difference from the results of studies that used different methods from the AHP. In a study that conducted a survey on users of a residential complex [41] and studies focused on field surveys [3,28], "site selection" was considered an important item, along with "recycling of topsoil" and "use of rainwater." The AHP model has the benefit of having the importance of assessment items determined by the experience and expertise of field experts and thus has greater value in terms of field applicability compared to other studies based only on a literature review or user survey.

Second, G-SEED is mostly focused on buildings. There is a perception gap between architects and landscape architects in the calculation of weightings for the landscape sustainability assessment items. Landscape architects gave higher weightings than architects to "soil and vegetation." This is because they directly handle plants and deal with planting, and thus, they better understand and emphasize this item. This is similar to the finding of previous research [11] on the perception gap in landscape-architecture importance, showing that multilayered planting structure and diversity of plant species score high in landscape. It is also similar to the actual sustainability strategies and methods of the SITES in the US for soil, vegetation, water circulation management, and landscape materials [4], implying that it is necessary to develop objective landscape assessment items that have been overlooked in the existing building assessment criteria. 
Third, the results of applying this assessment system to three G-SEED certified projects showed that while there was a slight difference in score overall, similar trends with criteria and factors are considered important from a landscape sustainability perspective. After analyzing the weighted average score for each field, we found that "maintenance" had the highest score with a relatively low score in "water" and "materials" in the three projects. These results indicate a need for more interest and effort in sustainable water management and material usage in Korea. In addition, the result revealed that Renaissance had a relatively high score of 'protection of cultural heritage', which highlighted the efforts to preserve architectural history in creating outdoor space. Considering these results derived from this assessment system, the assessment model of this study can be instrumental in supplementing G-SEED, which has relatively fewer assessment criteria for outdoor spaces. That is, a landscape-centered assessment system with various items would be useful in identifying outdoor sustainability issues and providing concrete solutions for the issues [42]. Therefore, continued efforts will be required to establish an assessment system for landscape sustainability that suits the Korean local context.

\section{Conclusions}

Many issues have been raised, including the notion that the landscape items of Korean sustainability certification are relatively scant and limited in terms of assessment and effectiveness, and thus, urgently require supplementation $[3,4,10]$. Therefore, to develop independent assessment factors to objectively assess landscape sustainability, this study derived items-including ecological value of the existing site, biotope creation, soil, vegetation, and water circulation management-not included in the existing assessment systems focusing on buildings and rated their importance using the AHP. The results showed that the existing G-SEED is inadequate for landscape assessment in many ways, and thus, there is a need for a differentiated certification system for landscape sustainability. Moreover, presenting the purpose and technology should be considered, rather than merely focusing on rating quantitative achievement, as should making assessment in terms of landscape performance, such as various creative sustainability strategies or technologies. In Korea, preliminary certification is often obtained at the end of the designing stage and main certification at the point of completion, for incentives. Thus, even though it is important in terms of reality, there are limitations in applying for certification in terms of post-occupancy evaluation or from the users' perspective. It is necessary to establish the system to evaluate sustainability in the entire process of the project, including design, construction, and maintenance. However, this study's significance lies in deriving assessment items that are applicable to landscape, instead of using the existing system in Korea that is focused on buildings, calculating weightings, and analyzing the trend based on specific cases of application, thereby presenting the possibility of developing a rational landscape assessment system.

Author Contributions: H.-S.L. designed the research and analyzed the data; E.-Y.P. designed the research and collected the field data. Both authors read and approved the final manuscript. All authors have read and agreed to the published version of the manuscript.

Funding: This research was funded by the Kyungpook National University Research Fund, 2017.

Conflicts of Interest: The authors declare no conflict of interest. The founding sponsors had no role in the design of the study; in the collection, analyses, or interpretation of data; in the writing of the manuscript; or in the decision to publish the results.

\section{References}

1. Han, S.A.; Kim, S.W. A Study on the Application Characteristics of Environment-Friendly Design Guidelines at Outdoor Spaces in Apartment Complexes-Focused on Turn-Key Projects of Han River New Town Construction. J. Korea Inst. Ecol. Archit. Environ. 2011, 11, 97-106.

2. Yang, W.S.; Chu, B.A. Study on Comparative Analysis of the Green Building Certification Criteria for Schools in Remodeling. J. Korean Inst. Inter. Des. 2011, 20, 182-189. 
3. Yoon, Y.H.; Kim, J.H.; Kim, S.D. Change of Ecological Environment Sector Based on the Comparative Analysis of Revision Green Building Certification Standards Apartment Housing. Seoul Inst. 2011, 12, 17-31.

4. Lee, H.S. A Study on Sustainable Outdoor Design Strategies and Assessment System through Analysis of SITES Certified Projects. J. Korean Inst. Landsc. Archit. 2016, 44, 56-64. [CrossRef]

5. Green Business Certification. SITES V2 Rating System for Sustainable Land Design and Development; Sustainable Sites Initiative: Austin, TX, USA, 2014.

6. BREEAM. Available online: www.breeam.com (accessed on 3 March 2019).

7. SBTool. Available online: www.iisbe.org/sbmethod (accessed on 3 March 2019).

8. CASBEE. Available online: www.ibec.or.jp/CASBEE (accessed on 3 March 2019).

9. Green Star. Available online: New.gbca.org.au/green-star (accessed on 15 March 2019).

10. Green Mark. Available online: www.bca.gov.sg/greenmark (accessed on 20 April 2019).

11. Lee, K.I.; Kim, M.S. A Study on the Preliminary Assessment Indicators for the Development of External Spaces of Ecological Housing Complexes through Practicing Architects' Survey. J. Archit. Inst. Korea Plan. Des. 2008, 24, 193-202.

12. Ajay, G. Sustainable by Design? J. Am. Plan. Assoc. 2009, 75, 424-440.

13. Lee, H.S. Assessment Items of Outdoor Environment through Analysis of SITES-Focused on the Comparison with G-SEED and LEED. J. Korea Inst. Ecol. Archit. Environ. 2014, 14, 11-18. [CrossRef]

14. G-SEED Certification Data. Available online: http://www.g-seed.or.kr (accessed on 22 February 2019).

15. Park, C.H.; Oh, M.W.; Kim, B.S. A Comparative Analysis Study of Green Building Certification Criteria-Focusing on the Site and Environment. Korean Sol. Energy Soc. 2009, 09, 324-329.

16. Eom, S.Y.; Song, O.H.; Lee, M.H. A Study on the Green Building Certification Criteria for Sustainable Urban Development. Korea Plan. Assoc. 2012, 47, 19-31.

17. Yoon, C.J. A Study on the Structure and Application of Environmental Performance Assessment System for Urban Development Project through the Analysis of CASBEE-UD in JAPAN. J. Archit. Inst. Korea Plan. Des. 2009, 25, 249-256.

18. Choi, J.M.; Kim, D.Y.; Kim, M. Comparison of the Foreign Environmental Communities Certification System-Focused on CASBEE CITY, CASBEE UD, BREEAM C, LEED ND. J. Korean Inst. Archit. Sustain. Environ. Build. Syst. 2012, 6, 99-105.

19. Kim, S.U.; Kim, H.B. Study on the Improvement of Korea Green Building Certification System by the Comparison with BREEAM and LEED. J. Archit. Inst. Korea Plan. Des. 2010, 26, 271-278.

20. Park, J.C.; Jeon, B.K.; Rhee, D.J. A Study on Comparing and Analyzing for Green Building Certification Criteria. J. Korean Inst. Archit. Sustain. Environ. Build. Syst. 2009, 3, 104-115.

21. Kim, H.K.; Lee, S.H. A Case Study on the Outdoor Space of Apartment Housing in Cheongju City by Using Green Building Certification. J. Inst. Constr. Technol. 2007, 26, 93-101.

22. Oh, S.H.; Chang, S.Y.; Kim, S.K.; Lee, K.I. A Study of the Assessment of Environment-Friendly Outdoor Spaces in Housing Estates. J. Archit. Inst. Korea Plan. Des. 2004, 20, 199-206.

23. Yoo, C.G.; Byun, K.H.; Cho, S.J. Defining a Village-Focused Green Index and Evaluating Value Structures using AHP-Focused on Rural Area. J. Reg. Assoc. Archit. Inst. Korea 2014, 16, 41-48.

24. Bae, S.W. A Study of Planning Indicators for the Creation of Environment-friendly External Space in Apartment House Regeneration Projects. Ph.D. Thesis, Dankook University, Cheonan, Korea, 2013.

25. Bae, S.H.; Song, O.H. A Study on the Actual Condition and the Effect of KGBCC-Based on Apartment Houses. J. Archit. Inst. Korea Plan. Des. 2010, 26, 61-70.

26. Lim, S.N.; Lee, J.H. A Study on Development of the Friendly Environment Valuation Indicator for the Exterior Space of Complex. Hous. Stud. Rev. 2006, 14, 195-220.

27. Choi, Y.J.; Lee, S.C. Analyzing the Weight of Assessment Criteria in Korea Green Building Certification System. J. KIEAE 2012, 12, 83-90.

28. Choi, Y.; Song, B.H.; Yang, B.E. A Study on the Improvement and Application of Environmentally-Friendly Factors at Outdoor Spaces in Apartment Complexes. J. Korean Inst. Landsc. Archit. 2007, 35, 37-49.

29. Ryu, J.W.; Jung, E.H.; Kim, D.W. A Study on the Design Elements Comparison of Environmental-Friendly Apartment Housing. J. Korean Hous. Assoc. 2005, 16, 29-35.

30. Ye, T.G.; Kim, K.H.; Kwon, Y.S. Complementary measures for Environmental Performance Evaluation Index of External Space of Green Standard for Energy and Environmental Design for Apartment Complex. J. Archit. Inst. Korea Plan. Des. 2018, 34, 3-14. 
31. Lepetu, J.P. The Use of Analytic Hierarchy Process (AHP) for Stakeholder Preference Analysis: A Case Study from Kasane Forest Reserve, Botswana. J. Soil Sci. Environ. Manag. 2012, 3, 237-251.

32. Kim, H.R. A Study on the Eco-friendly Evaluation of Traditional Hanok-Based on the G-SEED 2016 Certification Criteria. J. Korean Rural Archit. Assoc. 2018, 20, 77-84.

33. Chun, C.Y.; Kim, K.H.; Kim, H.J. Analysis on Consumers' Value about Environmental-Friendly Interior Finishing Material by Analytic Hierarchy Process. J. Korean Hous. Assoc. 2005, 16, 109-121.

34. Saaty, T.L. The Analytic Hierarchy Process, 3rd ed.; McGraw-Hill: New York, NY, USA, 1980.

35. USGBC. LEED for New Construction; v2.2; US Green Building Council: Washington, DC, USA, 2008.

36. USGBC. LEED 2009 for New Construction and Major Renovations; US Green Building Council: Washington, DC, USA, 2009.

37. USGBC. LEED 2009 for Neighborhood Development; US Green Building Council: Washington, DC, USA, 2009.

38. Seattle.gov. Available online: www.seattle.gov (accessed on 25 July 2019).

39. Developing a Green Factor Tool for City of Helsinki. Available online: https://ilmastotyokalut.fi/developinga-green-factor-tool-for-city-of-helsinki (accessed on 27 July 2019).

40. Dolan, J.G. Shared Decision-making-Transferring Research into Practice: The Analytic Hierarchy Process (AHP). Patient Educ. Counc. 2008, 73, 418-425. [CrossRef]

41. Lee, S.S. Research on Development Scheme for Sustainable Habitat. Master's Thesis, Hongik University, Seoul, Korea, 2001.

42. Seong, S.T.; Yu, S.E.; Yang, S.W. Open space design for certificated green apartment housing. Urban Des. Inst. Korea 2012, 13, 83-92.

(C) 2019 by the authors. Licensee MDPI, Basel, Switzerland. This article is an open access article distributed under the terms and conditions of the Creative Commons Attribution (CC BY) license (http://creativecommons.org/licenses/by/4.0/). 